\title{
Financial Stability, Leverage, Ineffective Monitoring, Independent Audit Committee, and the Fraudulent Financial Statement
}

\author{
Fenny Tjen ${ }^{1}$, Tigor Sitorus ${ }^{2}$, Rina Nur Chasanah ${ }^{1}$ \\ 1. Department of Accounting, Bunda Mulia University \\ Jl. Ancol Barat IV, RT.12/RW.2, Ancol, Kec. Pademangan, Kota Jkt Utara, Daerah Khusus Ibukota Jakarta 14430 \\ 2. Magister Program, Bunda Mulia University \\ Jl. Ancol Barat IV, RT.12/RW.2, Ancol, Kec. Pademangan, Kota Jkt Utara, Daerah Khusus Ibukota Jakarta 14430
}

\section{ARTICLE INFO}

Keywords:

Stability,

Leverage,

Monitoring,

Committee,

Fraud

Kata Kunci:

Stabilitas,

Pengaruh,

Memonitor,

Komite,

Kecurangan
A B S T R A C T

This study aims to develop prior empirical model research of factors influence toward fraudelent financial statement and determine some element of fraud triangle that are financial stability, Leverage , ineffective monitoring and one element of Good Corporate Governance that is independent audit committee influence to fraudulent financial statement. This research topic is important because investors need earnings information as a basic for making investment decision and fraudulent financial statement may affect quality of earnings information received by investors. Data obtained from financial statement of mining company period 2011-2015, data were analyzed with multiple linier regressions with 150 samples collected by purposive sampling technique. Then the authors used Micro soft Excel and SPSS version 24 for processing and analyzing samples. The results showed only financial stability that has a significant influence on fraudulent financial statement, while Leverage, ineffective monitoring and independent audit committee partially has not significant influence toward fraudulent financial statement.

SARI PATI

Penelitian ini bertujuan untuk mengembangkan model penelitian empiris sebelumnya tentang faktor-faktor yang berpengaruh terhadap kecurangan laporan keuangan dan mengetahui beberapa elemen unsur segitiga kecurangan yaitu; stabilitas keuangan, leverage, pemantauan yang tidak efektif dan elemen Good Corporate Governance yaitu pengaruh komite audit independen terhadap kecurangan laporan. Topik penelitian ini penting karena investor memerlukan informasi keuangan sebagai dasar untuk membuat keputusan investasi karena laporan keuangan yang curang dapat mempengaruhi kualitas informasi atas pendapatan yang akan diperoleh investor. Data diperoleh dari laporan keuangan perusahaan pertambangan periode 2011-2015, data dianalisis dengan regresi linier berganda dengan 150 sampel yang dikumpulkan dengan 
teknik purposive sampling. Kemudian penulis menggunakan Micro soft Excel dan SPSS versi 24 untuk memproses dan menganalisis sampel. Hasil penelitian menunjukkan hanya stabilitas keuangan yang memiliki pengaruh signifikan terhadap kecurangan laporan keuangan, sedangkan leverage, pemantauan yang tidak efektif serrta komite audit independen secara parsial tidak memiliki pengaruh signifikan terhadap kecurangan laporan keuangan

(C) 2020 IRJBS, All rights reserved.

\section{INTRODUCTION}

The final process in an accounting cycle is obtained results in the form of financial Statement. The financial statement reflects the company's condition within a certain period of time. This information is addressed to the parties concerned as a form of corporate responsibility for the flow of investment funds and credit into the company as well as consideration for making rational decisions about investing, crediting and similar decisions.

Recognizing the importance of information content in financial Statement, making managers motivated to improve the performance of the company so the existence of the company will remain intact. However there are cases where managers fail to achieve their performance goals so that the information that will appear in the financial Statement will not be satisfactory. So it is still often the case of mistakes and fraud in the context of recording and financial reporting to make the existence of the company stay awake, (Diany \& Ratmono, 2014)

Evidently, One form of fraud that occurred was done by PT Garda Tujuh Buana (GTBO) which suffered losses up to IDR. 21.52 billion in 2011, but in 2012 the financial report saw a profit of up to IDR .74 billion. After further observation, PT. GTBO divides revenue into three parts, one of which is miscellaneous sales of IDR. 711.15 billion, which is a down payment on the sales agreement of 10 million tons of coal whose new contract will be signed on June 14, 2012, (Indonesian Stock Exchange, 2017).
Research conducted by Kurnia \& Marsono, 2014) on external pressure and ineffective monitoring, on fraudulent financial Statement conducted on companies subject to sanctions from "Bapepam or Capital Market Supervisory Board" shows result that has not significant influence.

While Research on financial stability, personal financial need toward fraudulent financial statement in companies imposed sanction from "Bapepam" by Martantya \& Daljono, 2013) showed only financial stability which significantly influence fraud financial report, while personal financial need has not significant effect on fraudulent financial Statement. Furthermore, the study of an independent audit committee conducted by Handoko \& ramadhani (2017) shows that the independent audit committee has not significant effect on financial reporting fraud. A study conducted by Aprilia (2017) showed only financial stability variable which had significant effect while other variable studied showed hast not effect to fraudulent financial Statement. Research conducted by Tiffani \& Marfuah (2015) shows the financial stability and External pressure has positive and negative influence to fraudulent financial statement.

The research to be researched is different from previous research because this research not only examines the element of fraud triangle but also examines one element of good corporate governance, the sector that is sampled in this research is also a mining sector with multiple linier regression analysis method, while research earlier 
using a sample of manufacturing companies or companies that received sanction from "Bapepam" by logistic regression analysis method.

This study is different with the research conducted by Hogan, C.E. et. al (2008) that found factors influence of financial statement fraud are characteristics of firms, the procedures and abilities of auditors to detect fraud, also Donelson et. al. (2017) found that material weaknesses and future fraud revelation in entity-wide controls, not process-level controls, are associated with a higher risk of reporting fraud, while this study tried to develop prior research and find out other factors that influence on financial statement fraud like ; financial stability, leverage, ineffective monitoring, independent audit committee. While Fleming et.al. (2016) examine differences in the profile of financial reporting fraud between private companies and public companies and found that public company fraud are larger than in private company.

Regarding research background, so the problems in this study are: 1). Does financial stability has a significant positive effect on fraudulent financial statement? 2).Does the Leverage has a significant negative effect on the fraudulent financial statement? 3). Does ineffective monitoring have a significant negative effect on the fraudulent financial statement? 4). Does the independent audit committee has a significant negative effect on the fraudulent financial statement?

\section{LITERATURE REVIEW}

\section{Financial Statement}

According with Wantah (2015), regarding the presentation of financial Statement, the definition of financial Statement is a structured presentation of the financial position and financial performance of an entity. The financial Statement includes part of the financial reporting process. Complete financial Statement usually include income statement, statement of changes in equity, statement of financial position, Statement of cash flow, and other records and reports and explanatory materials that are an integral part of the financial Statement. The purpose of financial Statement is to provide information pertaining to the financial position, performance, and changes in the financial position of a company that benefit a large number of user in economic decision-making, (Ikatan Akuntan Indonesia (IAI), 2015). So that the financial Statement describes the actual financial condition, a quality audit system is needed (Setyaningrum et.al. 2013).

While according to SAS No. 99 in Jefri \& Mediaty (2014), financial statement fraud can be done in various ways, including: 1). Manipulation, forgery, or alteration of accounting records, supporting documents of the financial Statement drawn up, 2). A deliberate or deliberate omission in the information which is significant to the financial Statement. 3).Deliberately misusing principles relating to quantity, classification, presentation, or disclosure.

\section{Fraud}

In SAS (2002) states that fraud is deliberate in generating material misstatement in the financial Statement that is the subject of an audit. In the book Auditing and Assurance Services Arens, Elder, and Beasley (2009) SAS No.99 (AU 316) distinguishes two types of misstatement: error and fraud. Both types of miss statement can be material or immaterial. Errors are miss statement in unintentional financial Statement, while fraud is a deliberate misstatement. The concept of Fraud Triangle also relies on the research of Donald Cressey (1953) which concludes that fraud has three common properties: Pressure according to Rustendi, 2009 in Diany \& Ratmono (2014), Pressure can occur when management is in need of money to meet personal needs such as pressure for medical expenses, pressure from families demanding economic success, luxury living. According to Skousen, Smith, \& Wright, (2008), pressure can also arise when the company's performance is at a point below the industry's average performance. In SAS No. 99 (2002), there are four types of common conditions occurring at 
pressures that can lead to fraud. These conditions are financial stability, external pressure, personal financial need, and financial target.

\section{Financial Statement fraud}

Researcher that conducted a study about the influence factors Financial Statement fraud such as; Zainudin \& Hafiza Aishah Hashim (2016) found that financial leverage, asset composition, profitability and capital turnover were significant predictors of fraudulent financial reporting.

In order to distinguish between companies indicated to fraud or non-fraud required a model of calculation that can help detect matters in the financial Statement, namely Beneish M-Score Model, while if Beneish M-Score is greater than -2.22, it is categorized as a fraud company and otherwise if smaller than -2.22 , categorized as a company that does not do fraud, (Tiffani \& Marfuah , 2015).

The index number is obtained from several ratios as follows Messod Beneish (2011);

“1). DSRI = Days' Sales in Receivables Index. This measures the ratio of days' sales in receivables versus prior year as an indicator of revenue inflation; 2). GMI = Gross Margin Index. This is measured as the ratio of gross margin versus prior year. A firm with poorer prospects is more likely to manipulate earnings; 3 ). AQI = Asset Quality Index. Asset quality is measured as the ratio of non-current assets other than plant, property and equipment to total assets. $\mathrm{AQI}$ is the ratio of asset quality versus prior year; 4). SGI = Sales Growth Index. This measures the ratio of sales versus prior year. While sales growth is not itself a measure of manipulation growth companies are likely to find themselves under pressure to manipulate in order to keep up appearances; 5).DEPI = Depreciation Index. This is measured as the ratio of the rate of depreciation versus prior year. A slower rate of depreciation (DEPI greater than 1) may means that the firm is revising useful asset life assumptions upwards, or adopting a new method that is income friendly; 6).SGAI = Sales, General and Administrative expenses Index.This measures the ratio of SGA expenses to the prior year. This is used on the assumpton that analysts would interpret a disproportionate increase in sales as a negative signal about firms future prospects; 7). LVGI = Leverage Index. This measures the ratio of total debt to total assets versus prior year. It is intended to capture debt covenants incentives for earnings manipulation; 8).TATA=Total Accruals to Total Assets, This assesses the extent to which managers make discretionary accounting choices to alter earnings. Total accruals are calculated as the change in working capital accounts other than cash less depreciation."

\section{Financial stability}

In accordance with Statement on Auditing Standard (SAS) number 99 (AICPA, 2002), managers face pressures related to financial statement fraud when financial stability and / or profitability are threatened by economic, industrial or operating conditions, (Sihombing \& Rahardjo, 2014). Where firms experience growth then it will be below the industry average so managers will manipulate financial Statement to look better. But with the rapid growth of the company will still manipulate the financial Statement for the growth looks more stable.

According to Darmawan \& Sariati Oktoria Saragih (2017) that found a positive effect of variable quality auditor against fraudulent financial report, found a negative influence financial stability and financial variables against the target of fraudulent financial Statement. Financial stability is a company's financial condition from stable condition. The financial variable is proxy by using asset growth rate (ACHANGE). According to Martantya \& Daljono (2013), while the formula of ACHANGE is Total Asset t minus Total Assett-1 devided Total Asset t.

\section{Leverage}

Financial leverage according to Subramanyam and Wild (2010) is a measurement of the relationship between total assets and ordinary equity capital used to fund assets. For companies that successfully use leverage, a high financial leverage ratio 
increases returns on equity. In line with this, the risk associated with changes in profitability is higher if the financial leverage ratio is higher, while Ferdinand \& Setyarini Santosa (2018) found that leverage does not has significant effect on the fraudulent financial statement report. According to Aprilia (2017), Leverage is indicated by Total Liability devided Total Asset.

\section{Ineffective Monitoring}

The agency relationship will occur if the principal hires another person, in this case the agent to carry out the work that has been dedicated by the principal. The agency relationship can cause some problems due to the asymmetry of information between the principal and the agent. This information asymmetry can be a gap for fraud. In order to avoid fraud practices within the company, a supervisory unit is required to monitor the company's operations.

The widespread of accounting scandals and fraudulent practices is one of the effects of weak supervision by companies that have given an opportunity to act in accordance with their personal interests. With ineffective supervision, management will feel less closely monitored and more freely seeking ways to maximize its personal benefits. Therefore, to prevent the occurrence of fraud, other parties are required that Independent Board of Commissioners (Martantya \& Daljono, 2013).

Board of commissioners is widely believed to play an important role especially in monitoring top management. With the existence of an independent board of commissioners, it is expected that more effective corporate oversight and cheating or fraud practices can be minimized. With the employment of a commissioner who has no relationship with shareholders, directors, management or other internal parties, he will conduct more independent oversight of Martantya \& Daljono (2013). Therefore, the effectiveness of supervision is proxy by the ratio of independent board of commissioners. The formulation of the proportion of independent board of commissioners as follows: Number of Independent commissioners devided by total number commissioners.

\section{Audit Committee}

As stated by Hasnati in Agoes \& Ardana (2013), the Audit Committee is defined as a Committee established by and responsible to the Board of Commissioners in assisting in carrying out the duties and functions of the Board of Commissioners.

According to the National Commission on Governance Policies (2011), the Audit Committee is responsible for assisting the Board of Commissioners to ensure that: a). The financial Statement are presented fairly in accordance with generally accepted accounting principles, b). The company's internal control structure is well implemented, c). Implementation of internal and external audits carried out in accordance with applicable audit Standards, d). Follow-up results findings carried out by management. Furthermore, the study conducted by Mbobo \& Adebimpe Otu Umoren (2016) found that certain audit committee attributes namely; independence, meeting attendance, size and the existence of a written charter exert significant influence on the Quality of Financial Report. Also Gladys Lee \& Neil L. Fargher (2018) find that a higher-quality audit committee is associated with the implementation of a stronger internal whistle-blowing system, which in turn reduces the likelihood of external relative to internal reporting, also the study conducted by Ferdinand \& Setyarini Santosa (2018) found that audit committee characteristic does not has significant effect on the fraudulent financial Statement report.

According to theory and prior research, so authors built an empirical model of this research as bellow;

Based on this explanation, the following hypothesis is proposed:

\section{H2: Managerial ownership influences income smoothing.}




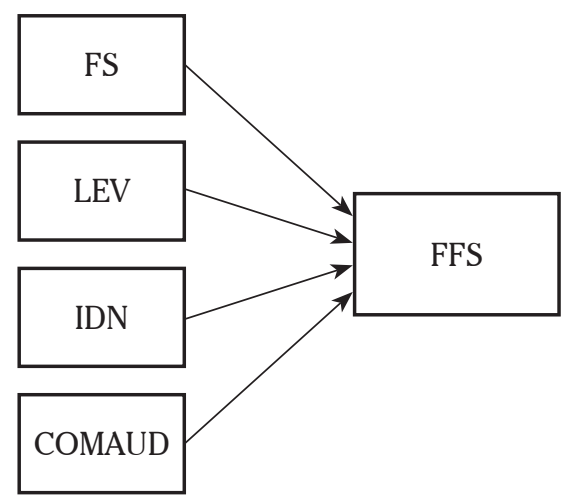

Picture 1. Model Empirical Reseach

Notes:

$$
\begin{array}{ll}
\text { FFS } & =\text { Fraudulent Financial Statement } \\
\text { FS } & =\text { Financial stability } \\
\text { LEV } & =\text { Leverage } \\
\text { IDN } & =\text { Ineffective Monitoring } \\
\text { COMAUD } & =\text { Independent Audit Committee }
\end{array}
$$

Based on figure 1, we may desrcribe as a state of the art of this study that Fraudulent Financial Statement may influenced by several variables such as; Financial stability, Personal Financial Need, External Pressure, Ineffective Monitoring, Independent Audit Committee.

\section{METHODS}

\section{Population and Sample}

The populations in this study are all mining companies listed on the Indonesia Stock Exchange (BEI) during the period 2011-2015 which is a number of 42 companies.

The sampling company in these research equal 30 companies for 5 years, so data observed as samples equal 150 that meet the criteria of Purposive sampling as follows:

1. Mining companies listed successively in Indonesia stock exchanges during 2011-2015.

2. Company that has a closing date of 31 December

3. Companies that publish annual financial Statement on the BEI website using the Rupiah and US Dollar currencies.

4. Data related to complete research variables.

\section{Operationalization Variable}

a. Fraudulent Financial Statement (Y), With Corporate indicators categorized into companies that are indicated to conduct fraud if it has a value of Beneish M Score > -2.22 and otherwise if Beneish M Score $<-2.22$ then the company is categorized into companies that are not indicated to conduct fraud, (Tiffani \& Marfuah, 2015)

b. Financial Stability (ACHANGE, X1), with indicator Ratio Growth Total assets, Leverage (LEV, X2) that indicated by Percentage ratio of total debt to total assets, (Aprilia, 2017)

c. Ineffective Monitoring (IDN, X3), the number of independent commissioners is divided by the number of board of commissioners within the company, (Kurnia \& Marsono, 2014)

d. Independent Audit Committee (COMAUD, X4), Percentage of comparison of independent audit committee with number of audit committee of company, (Ferdinand \& Setyarini Santosa, 2018)

The Data used in this research is quantitative data that is secondary data in the form of financial report and annual report of mining sector company period 2011-2015 obtained from Indonesian Stock Exchange, (Indonesian Stock Exchange, 2017)

\section{Technique Analysis}

Stages of data processing in this study starts from the analysis of annual report data, financial Statement of mining companies associated with variables to be studied. Then the data tabulated into Microsoft Excel and to process research data, researchers use IBM SPSS (Statistic Program for Social Science) to test data and research hypothesis.

\section{RESULTS AND DISCUSSION}

\section{Analysis descriptive statistic}

Furthermore, authors present tables as a basis for analyzing descriptive of variables, determination coefficient test and individual parameter significant test as bellows. 
Table 1. Statistic Descriptive of variables

\begin{tabular}{lcrrrr}
\hline & $\mathrm{N}$ & Minimum & Maximum & Mean & Std. Deviation \\
\hline FFS & 150 & -6.88 & .26 & -2.7972 & 1.14497 \\
\hline ACHANGE & 150 & -.97 & .56 & -.0392 & .21800 \\
\hline LEV & 150 & .07 & .94 & .4796 & .20313 \\
\hline IDN & 150 & .20 & .67 & .3990 & .10716 \\
\hline COMAUD & 150 & .33 & 1.00 & .6436 & .14505 \\
\hline Valid N (listwise) & 150 & & & & \\
\hline Source Output SPSS Statistic 24 & & & & &
\end{tabular}

Source : Output SPSS Statistic 24

Based on table-1, bellow can explain the descriptive statistic of variable such as;

The Fraudulent financial statement (FFS) variable proxy using the Beneish M-Score with a total of 150 data have the lowest value -6.88 and the highest value of 0.26 with an average value of -2.7972 or smaller than Beneish M-score $(-2,22)$ and the Standard deviation equal 1.14497 (Standard Deviation > Mean). It is mean that on average there is no fraud in the company.

The financial stability variables proxy using the asset growth rate (ACHANGE) with a total of 150 data have the lowest value -0.97 in Perdana Karya Perkasa Tbk, and the highest value of 0.56 in Benakat Integra Tbk, with an average value of -0.392 and the Standard deviation of 0.21800 (Standard Deviation $>$ Mean). It is mean that on average there is financial instability in the company.

The external-party pressure variable produced using leverage ratio (LEV) with total data of 150 has the lowest value of 0.07 in Timah Persero Tbk, and the highest value of 0.94 in PT Delta Dunia Makmur Tbk, with the average value of $0.4796(47,96 \%)$ and the Standard deviation of 0.20313 . It is mean that on average there is external-party pressure in the company.

Ineffective monitoring variables (IDN) proxy using the proportion of independent board of commissioners with total data of 150 has the lowest value of 0.20 at Investido Tbk's partner company, and the highest is 0.67 in some companies and has an average value of 0.3990 or almost $40 \%$ with a Standard deviation of 0.10716 . It is mean that on average there is effective monitoring in the company.

The independent audit committee variable in Good Corporate Governance proxy using the proportion of independent audit committees with a total of 150 data has the lowest value of 0.33 in some firms, and the highest score of 1.00 is also in some companies, and has an average value amounted to 0.6436 $(64,36 \%)$ with a Standard deviation of 0.14505 . It is mean that on average there is effective monitoring in the company.

\section{Determination Coefficient Test $\left(\mathrm{R}^{2}\right)$}

Table 2. Determination Coefficient Test $\left(\mathrm{R}^{2}\right)$

\begin{tabular}{lccrc}
\hline Model & R & R Square & $\begin{array}{r}\text { Adjusted } \\
\text { R Square }\end{array}$ & $\begin{array}{c}\text { Std. Error } \\
\text { of the } \\
\text { Estimate }\end{array}$ \\
\hline 1 & $.777^{\text {a }}$ & .604 & .573 & .74857 \\
\hline Source: Output SPSS Statistic 24 & &
\end{tabular}

Based on Table 2 the magnitude of adjusted $\mathrm{R}$ Square is 0.573 , this means $57.3 \%$ variation in the possibility of fraudulent financial statement can be explained by the variation of the five independent variables i.e. ACHANGE, LEV, IDN, COMAUD. While the remaining of $42.7 \%$ is explained by other variables that come from outside of this model.

\section{Individual Parameter Significant Test (Test Statistic $\mathrm{t}$ )}

Based on Table 2 the magnitude of adjusted $\mathrm{R}$ Square is 0.573 , this means $57.3 \%$ variation in the possibility of fraudulent financial statement can be 
Table 3. Individual Parameter Significant Test (Test Statistic t)

\begin{tabular}{|c|c|c|c|c|c|c|}
\hline \multirow[b]{3}{*}{ Model } & & \multicolumn{2}{|c|}{ Unstandardized } & \multirow[b]{3}{*}{$\mathrm{T}$} & \multirow[b]{3}{*}{ Sig. } & \multirow{3}{*}{ Label } \\
\hline & & & & & & \\
\hline & & $\mathrm{B}$ & Std. Error & & & \\
\hline \multirow[t]{5}{*}{1} & (Constant) & -3.126 & .570 & -5.486 & .000 & \\
\hline & ACHANGE & 4.034 & .451 & 8.938 & .000 & H1: Accepted \\
\hline & LEV & -.385 & .454 & -.847 & .400 & H2: Rejected \\
\hline & IDN & .993 & .850 & 1.169 & .247 & H3: Rejected \\
\hline & COMAUD & .384 & .632 & .606 & .546 & H4: Rejected \\
\hline
\end{tabular}

Source: Output SPSS Statistic 24

explained by the variation of the five independent variables i.e. ACHANGE, LEV, IDN, COMAUD. While the remaining of $42.7 \%$ is explained by other variables that come from outside of this model.

Based on table 3 , the multiple regression equation in this research is:

$\mathrm{FFS}=-3.126+4.034 \mathrm{ACHANGE}-0.385 \mathrm{LEV}+$ 0.993IDN + 0.384COMAUD + error

Regarding the multiple regression equation that mention above, bellow can be explained the meaning of the coefficient;

1. The constant of -3.126 means that if ACHANGE, LEV, IDN, COMAUD are below 0 (negative), and then the possibility of fraudulent financial Statement proxy with the M-score value is $-3.126$.

2. ACHANGE regression coefficient of 4.034, meaning that if ACHANGE increase $1 \%$ then the possibility of fraudulent financial statement will increase by 4.034

3. LEV regression coefficient of -.385 , meaning if LEV increased $1 \%$ then the possibility of fraudulent financial statement will decrease by -.385 .

4. IDN regression coefficient of .993 , meaning if IDN increased 1\% then the possibility of fraudulent financial statement will increase by .993 .

5. COMAUD regression coefficient of .384 , meaning that if COMAUD experience increases $1 \%$ then the possibility of fraudulent financial statement will increase .384.
Based on table 3, then authors try to prove the relationship intervariable as bellows;

1). The influence of Financial Stability on The of Fraudulent Financial Statement (Hypotheses-1)

Based on the result of $t$ test with significant level of $5 \%$ ( $\alpha=0.05)$, obtained financial stability value which is a proxy of fraud triangle of $0.00<0.05$ and a positive regression coefficient of 4,034 . That is, financial stability has a significant positive effect on fraudulent financial statement.

The results of this study are in line with research conducted by Manurung \& Hadian (2013), Martantya \& Daljono (2013), Sihombing \& Rahardjo (2014), and Tiffani \& Marfuah (2015). According to Skousen in Martantya \& Daljono (2013) when financial stability or profitability is threatened by the state of the economy, the industry, and the situation of the operating entity, managers face the pressure to commit fraudulent financial Statement. Companies that have large assets tend to not perform financial stability in an attempt to attract investors to invest in the company. Companies that have small assets or large assets but large cash outflows also have the opportunity to manipulate to make the company's financial stability looks good. In order to achieve financial target, companies will be encouraged to use accounting method that will increase or decrease the value of company asset such as fair value mechanism and asset capitalization, (Martantya \& Daljono, 2013).

2). The influence of Leverage on The of Fraudulent Financial Statement (Hypotheses-2) 
Based on the result of $t$ test with significant level of $5 \%(\alpha=0.05)$, the value of significance of independent variable External Pressure is $0.40>$ 0.05 and negative regression coefficient is -0.385 . That is, External Pressure has no significant effect on the possibility of fraudulent financial statement. The results of this study are in accordance with Ferdinand \& Setyarini Santosa (2018), Aprilia (2017), Skousen, Smith, \& Wright (2008), The tendency of companies to fraud with low leverage characteristics is more likely to be caused by the current creditors not considering the amount of leverage generated, there are other considerations such as the level of trust or relationship between the company and creditors. In addition, many companies prefer to issue shares again to gain additional capital from investors without having to make new debt agreements that cause the company's debt burden to be greater Martantya \& Daljono (2013).

3). The influence of Ineffective Monitoring on Fraudulent Financial Statement (Hypotheses-3)

Based on the result of $t$ test with significant level of $5 \%(\alpha=0.05)$, the value of significance of independent variables ineffective monitoring is $0.247>0.05$ and the positive regression coefficient is 0.993 . This means that ineffective monitoring has not significant effect on fraudulent of financial Statement. The results of this study are in line with research conducted by Kurnia \& Marsono (2014) and Sihombing \& Rahardjo (2014). It is possible that the placement or addition of an independent board member is possible only to comply with the formal requirements of the IDX which requires an independent commissioner of at least $30 \%$ of the total number of existing commissioners, while the majority shareholder still plays an important role, therefore the performance of the board does not increase.

4). The influence of Independent Audit Committee

To The of Fraudulent Financial Statement (Hypotheses-4)

Based on the result of $t$ test with significant level of $5 \%(\alpha=0.05)$, obtained value independent variable independent audit committee significance of $0.546>0.05$ and the regression coefficient which is positive value of 0.384 . That is, the existence of an independent audit committee has not significant effect on the fraudulent acts of financial Statement. The results of this study are in line with research conducted by Handoko \& Ramadhani (2017), also Ferdinand \& Setyarini Santosa (2018). This result shows that the increasing number of independent audit committee members does not effectively reduce fraudulent financial Statement to the company. This is supported by the regulation of the financial services authority No.55 /POJK.04/ 2015 stating that the company or publicly-listed issuer is required to have an audit committee and its members shall consist of at least three persons where one independent commissioner and two others are from outside publicly listed company issuers. In other words, members of the audit committee must be independent.

\section{MANAGERIAL IMPLICATIONS}

This study contributed to developed several factor that influence fraudulent financial statement because evidently, leverage, ineffective monitoring and independent audit committee have not significant influence toward fraudulent financial statement. Meanwhile practically for principals not to over-emphasize the agent to avoid the occurrence of fraudulent actions that might be done, and for investors or potential investors, to be more careful in investing and in making decisions need to look at other factors and other conditions first, so that not only focus on the numbers in the financial Statement only, also for auditors, the results of this study are expected to be followed up as consideration in conducting an audit of the attached company.

\section{CONCLUSION}

The Fraudulent financial statement is positively and significantly influenced by financial stability $\left(\mathrm{H}_{1}\right.$ accepted). When financial stability is threatened by the economic, industrial, and entity 
circumstances, managers face the pressure to commit fraudulent financial Statement. This means that if financial stability of company is good and then Fraudulent financial Statement will lower. The results of this study are in line with research conducted by Tiffani \& Marfuah (2015), Sihombing \& Rahardjo (2014), Manurung \& Hadian (2013) and Martantya \& Daljono (2013).

The Fraudulent financial statement is negatively but not significantly influenced by Leverage $\left(\mathrm{H}_{2}\right.$ is rejected). This means even many companies prefer to issue stocks again to gain additional capital from investors without having to make new debt agreements that cause the company's debt burden to be greater. With the company obtaining a loan to acquire the company's assets it makes clear, how the asset was acquired, or whether the firm has an asset or not, thereby making the possibility of an external pressure insignificant to the possibility of a fraudulent financial statement. The results of this study are in accordance with Ferdinand and Setyarini Santosa (2018), Aprilia (2017).

The Fraudulent financial statement is positively but not significant influenced by Ineffective monitoring $\left(\mathrm{H}_{3}\right.$ is rejected). This means that even a monitoring is weak but Fraudulent financial statement still weak also. It is possible that the placement or addition of independent members of the board of commissioners is possible only to comply with the formal provisions of the IDX which requires an independent commissioner of at least $30 \%$ of the total number of existing commissioners, while the majority shareholder still plays an important role.
The results of this study are in line with research conducted by Sihombing \& Rahardjo (2014), Martantya \& Daljono (2013), Kurnia \& Marsono (2014).

The Fraudulent financial statement is positively influenced but not significantly by independent audit committee $\left(\mathrm{H}_{4}\right.$ is rejected). It is possible that the placement or addition of independent members of the board of commissioners is possible only to comply with the formal provisions of the regulatory authority of the financial services No.55 /POJK.04/ 2015 stating that the company or publicly-listed issuer is required to have an audit committee and its members shall consist of at least three one independent commissioner and two others from outside public company issuers. The results of this study are in line with research conducted by Ferdinand \& Setyarini Santosa (2018), Handoko \& Ramadhani (2017).

\section{Limitations of Research}

Several limitation of this study such as this study uses a limited sample only to the mining sector listed on the Indonesia Stock Exchange, while Fraudulent financial Statement are measured only by the M-score value of the Beneish Model calculation. Evidently, the independent variables in this study can only explain $57.3 \%$ of their influence on the detection of possibility, so for further research it is expected to increase the proxy of fraud variables for broader research coverage, such as foreign ownership, financial targets, privileged parties, (Kurnia \& Marsono, 2014) nature of industry, rationalization, (Tiffani \& Marfuah, 2015). 
REFEREN CES

Agoes, S. \& Ardana, I. C. (2013). Etika Bisnis dan profesi. Jakarta: Salemba empat.

Agustia, D. (2013). Pengaruh Faktor Good Corporate Governanace, Free Cash Flow, Dan Leverage Terhadap Manajemen Laba Keuangan. Jurnal Akuntansi Dan Keuangan, Vol. 15, No. 1, 27-42.

American Institute of Certified Public Accountant (AICPA), (2002). Statement on Auditing Standards (SAS) No. 99: Consideration of Fraud in a Financial Staetement Audit, AICPA". New York.

Aprilia. (2017). Analisa Pengaruh Fraud Pentagon Terhadap Kecurangan Laporan Keuangan Menggunakan Beneish Model Pada Perusahaan Yang Menerapkan Asean Corporate Governance Scorecard. Jurnal Akuntansi Riset Vol 6, No 1, , 109.

Arens, A. A., R. J. Elder \& M. S. Beasley, (2009). Auditing and Assurance Service: An Indonesia Adaptation. Prentice Hall

A. Scott Fleming, Dana R. Hermanson, Mary-Jo Kranacher \& Richard A. Riley, Jr. (2016), Financial Reporting Fraud: Public and Private Companies, Journal of Forensic Accounting Research December 2016, Vol. 1, No. 1, pp. A27-A41, https://doi. org/10.2308/jfar-51475.

Beneish Messod (2011), The Beneish M-Score: Identifying Earnings Manipulation and Short Candidates, Business Insider, https://www.businessinsider.com/the-beneish-m-score-identifying-earnings-manipulation-and-short-candidates-2011$5 / ? \mathrm{IR}=\mathrm{T}$

Chris E. Hogan, Zabihollah Rezaee, Richard A. Riley Jr. \& Uma K. Velury (2008) Financial Statement Fraud: Insights from the Academic Literature. AUDITING: A Journal of Practice and Theory: November 2008, Vol. 27, No. 2, pp. 231-252. https:// doi.org/10.2308/aud.2008.27.2.231

Dain C. Donelson, Matthew S. Ege, \& John M. McInnis (2017), Internal Control Weaknesses and Financial Reporting Fraud, AUDITING: A Journal of Practice and Theory, August 2017, Vol. 36, No. 3, pp. 45-69, https://doi.org/10.2308/ajpt-51608

Darmawan, Arif \& Sariati Oktoria Saragih (2017), The Impact Of Auditor Quality, Financial Stability, and Financial Target For Fraudulent Financial Statement, Vol 2 No 1 (2017): Journal Of Applied Accounting and Taxation (JAAT), DOI:Https://Doi. Org/10.5281/Zenodo.1306515

Diany, D. R., \& Ratmono, D. (2014). Determinan Kecurangan Laporan Keuangan : Pengujian Teori Fraud Triangle. Diponegoro Journal Of Accounting Volume 3, Nomor 2.

Ferdinand, Rian \& Setyarini Santosa (2018) Factors That Influence Fraudulent Financial Statement In Retail Companies Indonesia, JAAF (Journal Of Applied Accounting and Finance), Volume 2, Number 2, 2018, 99-109, http://e-journal. president.ac.id/presunivojs/ index.php/JAAF/article/view/ 548/348

Gladys Lee \& Neil L. Fargher (2018), The Role of the Audit Committee in Their Oversight of Whistle-Blowing, AUDITING: A Journal of Practice and Theory, February 2018, Vol. 37, No. 1, pp. 167-189 https://doi.org/10.2308/ajpt-51769

Handoko, L. B., \& Ramadhani, A. K. (2017). Pengaruh Karakteristik Komite Audit, Keahlian Keuangan, Dan Ukuran Perusahaan Terhadap Kemungkinan Kecurangan Laporan Keuangan. DeReMa Jurnal Manajemen Vol. 12 No. 1.

Ikatan Akuntan Indonesia (IAI) (2015). Standar Akuntansi Keuangan. Jakarta.

Komite Nasional Kebijakan Governance. (2011). Pedoman Good Corporate Governance Perusahaan Konsultan Aktuaria Indonesia. Jakarta,

Kurnia \& Marsono. (2014). Pengaruh Faktor-faktor Dalam Perspektif Fraud Triangle Terhadap Fraudulent Financial Reporting ( Studi Kasus Pada Perusahaan Berdasarkan Sanksi Dari Bapepam Periode 2008-2012. Diponegoro Journal Of Accounting Volume 3, Nomor 2.

Manurung, T. D., \& Hadian, N. (2013). Detection Fraud Of Financial Statment With Fraud Triangle. Proceedings Of 23rd International Business Reaserch Conference. Melbourne, Australia

Mbobo Erasmus Mbobo \& Adebimpe Otu Umoren (2016), The Influence Of Audit Committee Attributes On The Quality Of Financial Reporting Evidence From Nigerian Banks, International Journal of Economics, Commerce and Management United Kingdom Vol. IV, Issue 7, July 2016

Martantya, R. M., \& Daljono. (2013). Pendeteksian Kecurangan Laporan Keuangan Melalui Faktor Resiko, Tekanan dan Peluang (Studi Kasus pada Perusahaan Yang Mendapat Sanksi Bapepam 2002-2006). Diponegoro Journal of Accounting, 2(2), 1-12. Retrieved from http://id.portalgaruda.org/index.php? ref=browseandmod=viewarticleandarticle $=121360$.

SAS. (2002). Consederation Of Fraud In a Financial Statement Audit. AU Section 316, SAS No. 99, 3.

Setyaningrum, Dyah, Lindawati Gani, Dwi Martani \& Cris Kuntadi (2013), The Effect of Auditor Quality on the Follow-Up of Audit Recommendation, International Research Journal of Busines Studies (IRJBS), Vol. 6 No.2, pp. 89-104 DOI :https:// doi.org/10.21632/irjbs.6.2.

Sihombing, S. K., \& Rahardjo, N. S. (2014). Analisis Fraud Diamond Dalam Pendeteksian Financial Statment Fraud: Studi Empiris Pada Perusahaan Manufaktur Yang Terdaftar Di Bursa Efek Indonesia 2010-2012. Diponegoro Journal Of Accounting Volume 03, Nomor 02, 2.

Skousen, J. C., Smith, R. K., \& Wright, J. C. (2008). Detecting and Predicting Financial Statment Fraud. The Effectiveness Of The Fraud Triangle and SAS No. 99. 
Tiffani, L., \& Marfuah. (2015). Deteksi Financial Statment Fraud Dengan Analisis Fraud Triangle Pada Perusahaan Manufaktur Yang Terdaftar Di Bursa Efek Indonesia. JAAI Volume 19 No.2.

Wantah, M. J. (2015). Analisis Penerapan PSAK No.1 Tentang Penyajian Laporan Keuangan Pada Perum Bulog Divre Sulut dan Gorontalo. Jurnal Berkala Ilmiah Efisiensi Volume 15 No. 04, 76.

Zainudin Emie Famieza \& Hafiza Aishah Hashim, (2016), Detecting fraudulent financial reporting using financial ratio, Journal of Financial Reporting and Accounting, Vol. 14 Issue: 2, pp.266-278, https://doi.org/10.1108/JFRA-052015-0053

\section{Website :}

Indonesian Stock Exchange, (2017, August 10), Annual Financial Report, Retrieved from PT Bursa Efek Indonesia, http://www. idx.co.id 